\title{
FOUR PUSHKIN BIOGRAPHIES
}

The title of this review essay on four biographies of Alexander Pushkin (Slavic and East European Journal, vol. 48: 1 (2004): 77-97) refers to one of the most sacred clichés or "winged words" of Russian culture: "Pushkin is our everything" [Pushkin — nashe vsyo].

The phrase is attributed to the literary and theater critic Apollon Grigoriev (1822-64), who, in his 1859 survey of Russian literature since Pushkin's death, wrote: "Pushkin is our everything. Pushkin is the representative of all that is spiritual in us, all that is peculiar to us, he is that which remains spiritual and peculiar to us after all collisions with other and foreign worlds." A sentiment like this is a sitting duck for parody - and has been parodied since the moment of its utterance. But the essay below, which reviews four items from the cosmic fallout of the Pushkin Bicentennial of 1999, was conceived in a reverent spirit. If not absolutely everything, he is nevertheless infinite.

\section{OUR EVERYTHING} (2004)

T. J. Binyon, Pushkin: A Biography. London; HarperCollins, 2002, USA imprint New York: Alfred A. Knopf, 2003, xxix + 731 pp.

I. Surat and S. Bocharov. Pushkin. Kratkii ocherk zhizni i tvorchestva. Moscow: Iazyki slavianskoi kul'tury, 2002. 220 pp.

Ariadna Tyrkova-Vil'iams. Zhizn' Pushkina. Tom pervyi 1799-1824 [1929]; Tom vtoroi 18241837 [1948]. Rep. in series “Zhizn' zamechatel'nykh liudei.” Moscow: Molodaia gvardiia, 2002. Vol. 1: 468 pp.; vol. 2: 504 pp.

Feliks Raskol'nikov. Stat'i o russkoi literature, Part I: Pushkin. Moscow: Vagrius, 2002.

Now that the Jubilee harvest has been gathered in, inventory for a new century of "my Pushkins" can begin. Each of the biographical projects under review here - one by a British academic, another by a pair of professional Russian Pushkinists in Moscow, and two by émigrés of widely dissimilar generation and calling - has its own angle of vision on Pushkin: the Life. 
T. J. Binyon's enthralling narrative, with magisterial self-confidence, gives us the daily behavior of the outer man as it might appear to an observer distanced in time, place, and cultural perspective. With good reason has his achievement been called Tolstoyan in its scope and mercilessness. The "brief sketch" by Irina Surat and Sergei Bocharov announces itself as an "experimental book" in the opposite direction, an attempt to provide the "inner biography of an artist" as might be grasped "in a single glance." In her youth, Ariadna Tyrkova-Williams (b. St. Petersburg 1869, d. USA 1962) was a classmate and friend of Nadezhda Krupskaya, Lenin's wife. She became a Kadet activist, married a British journalist and emigrated, began working on her biography of Pushkin in London during the 1920s, and published the second volume only in 1948, when she was nearly eighty. Of the many scholarly and nostalgic tributes to the poet from the Russian diaspora, hers is the longest and perhaps the least known. Feliks Raskolnikov departs from the strictly biographical task, although a primary aim of his revisionist Essays on Russian Literature is to call into question today's methodologies for integrating the life with the works. Taken together, these four books not only bring Pushkin to life in a fascinating set of parallel stories, but can serve as object lessons in biographical recuperation - the most rewarding and risk-laden form of history practiced in the humanities.

\section{The outer man (Pushkin through T. J. Binyon)}

The 10 June 2003 issue of the Guardian ran a notice by John Ezard titled: "Crime writer’s Pushkin steals $£ 30,000$ prize." Binyon was a dark horse. Betting had been far higher on the six other bestsellers competing for the Samuel Johnson award, Britain's most generous. In that notice we also learn that Binyon is crime reviewer for the London Evening Standard, as well as author of two criminal mysteries and a study of the role of the detective in fiction. A university don and Slavist with teaching experience at Leeds and Oxford, he came to this bicentennial commission handsomely equipped in nineteenth-century social history and the Russian classics. Is there something about a crime writer's approach to Pushkin's life that might help explain this impressive success?

We might first note that Binyon is the British biographer of another nation's preeminent poet. He is creating the life story for an audience that knows the poet and his wonder-working words only at second hand. Under those conditions, what might be the relevant devices of a good detective? 
Come to the evidence with an open mind. Trust that the material world leaves traces. Stick to public documents in their proper order (the volume is prefaced by detailed genealogies and maps). Don't tell too much at once; attend to the contrary detail and to those obstacles that delay the easy end. Write vibrantly and without sentimentality. Assume a readership that values a rapid pace and cultivates a retentive memory capable of detecting a web of subtexts under every given fact. One nice design detail is the integration of dozens of Pushkin's line-sketches from his albums and notebooks - and this proximity of the poet's hand lends an energy to Binyon's narrative that recalls Khrzhanovsky's animated film from 1987, Liubimoe moe vremia (po risunkam Pushkina), where sketches start to gallop, lines of script wrap themselves around trees to resemble birch bark, and Pushkin's handwriting comes to life before our eyes. ${ }^{1}$ Such is Binyon's explicit target: the immediately available, visible outer man. To this end he peels back Jubilee encrustations, leaving the Pushkin Industry to the critics - and for this reason, he explains, "literary analysis has been eschewed" (xxix). Coherence and justification are not to be achieved through retrospection or myth, but must emerge linearly out of a chronological sequence, aided by the detective's eye for details in their original context. Later contexts and interpretive webs are overall off limits. On those rare occasions when Binyon engages a biographical piety (as with the encounter between Pushkin and the corpse of Griboyedov in the summer of 1829, described as a real event in Journey to Arzrum but demonstrably fictional), he corrects the facts neutrally in the text while noting the Russians' passionate adherence to the legend in a gloss (300).

These occasional exceptions to a biography "strapped to its subject's back" are themselves of interest. They all work to deflate the preening critic and enhance the multivalence of the artwork in its own time. When, for example, Binyon hops forward to Valery Briusov's 1909 essay on “The Bronze Horseman," this departure from his own stated procedures was most likely prompted by Briusov's essay itself, which discredits scholarly presumptions to decode the poem (436-37). Binyon's own discussion of the competing schools of "Queen of Spades" criticism - realistic and supernatural — appears similarly motivated; the two explanations coexist in perfect paradox, he

1 "A marvelous technique for replicating the creative process," writes Stephanie Sandler in her fine analysis of this whimsical and captivating film. See Stephanie Sandler, Commemorating Pushkin: Russia's Myth of a National Poet (Stanford: Stanford University Press, 2004), 156-67, esp. 160. 
claims, "the literary equivalent of one of those prints by Escher that conflates two mutually contradictory perspectives" (445-46).

Nevertheless, for the literary biographer "eschewing the critical industry" is arguably more defensible than eschewing discussion of the literary works themselves. Early reviews reproached Binyon on this score. James Wood closes his highly laudatory essay in the London Review of Books (February 20, 2003) with the caveat that the biography's "only fault is its lack of extended literary criticism"; Clive James, in a dazzling irreverent review in the Times Literary Supplement (September 27, 2002), remarks pointedly that Binyon "has declined to make a priority of crying up the poetry's uniqueness." The charge is unfair. True, Binyon takes for granted that Pushkin is the greatest poet in the Russian language, anchored there as Shakespeare is in our English. The formal perfection of the poetry is rarely addressed, and as a rule the plots are not retold. But Binyon's blank verse equivalents to the lyrics are clean and austere. There are some stunning life-contextualizations that cause the lyrics to jump off the page. For example, the rumor of Nikolai Turgenev's deportation to England in 1826 is adduced as a stimulus behind Pushkin's lyric about the sea as enabler of man's three-fold fate, to be "tyrant, traitor, or prisoner" (228); the sudden juxtaposition of the poet's madcap life with an inspired rendering of "The Prophet" (245) jolts the reader into realizing that Pushkin's mission is far more than meets the eye. The Belkin Tales especially receive succinct and insightful appreciation (384-85). By "eschewing literary analysis" Binyon need not be implying a disdain for the products of literary genius. But he is reluctant to enter that edifice of insiderly professional debate that relies on itself for its excitement, dissociated from the processes of primary creation. Binyon insists on returning Pushkin's works to their own time. No insulation, no props. So earnest is Binyon in this task that he would even strip away the myth that did accrue to poetry during the Romantic period, and to this immensely charismatic poet during his lifetime.

Up through 1825, Binyon segments Pushkin's life in the conventional ways: Ancestry and Childhood, the Lycée, St. Petersburg, the Caucasus and Crimea, Kishinev, Odessa, then Mikhailovskoe. Everywhere, emphasis is on movement. For the final decade, another organizing rubric applies: settling down. The years 1826-29 (Chapter 10) are titled - prematurely, it might seem - "In Search of a Wife." That chapter is followed by others marked by an equivalent intimacy, which reflect a circling down to home, hearth, grave: "Courtship," "Married Life," "The Tired Slave," "A Sea of Troubles," "The Final Chapter." The wife might be the Muse, but poetry itself is unable to save 
Pushkin in this fatal arc. The impression provided by the Table of Contents is of a powerful bellows, with the restless Pushkin first seeking freedom on the road or in changes of residence and then increasingly propelled inward, toward the final apartment on the Moika. What is absent from this trajectory is any mystique attending to the mission of a poet.

How to portray the poetic gift in its genesis and concreteness is a complex problem for a biographer, and Binyon has clearly thought hard about it. First, there are all the constraints of a relatively undramatic medium: a poet chewing at the tip of a quill pen is simply not as interesting to watch, hour after hour, as an architect realizing a building, Van Gogh over one of his canvases, or Mozart conducting Le nozze di Figaro. Second, consistent with his commitment to the outer man, Binyon respects Pushkin's privacy. The works do get written, but somehow at the edge of the picture, out of that excess of energy made available when the poet's body is temporarily or involuntarily stilled. The young poet, we read, got down to serious writing only when bedridden; venereal disease was the "wet-nurse" of Ruslan and Liudmila (90). The infuriating constraints that brought about the first Boldino autumn are given their due, with a useful inventory of the physical property on this distant estate and a chilling account of the cholera epidemic in Russia and Europe (338-45) - but Binyon will not linger on the divine creative miracle of that season. The occasional glimpse of Pushkin composing verse is registered (like almost everything else in this biography) as an outsider would look in on it, a person for whom the scene is bizarre in the extreme. Early one morning in Kishinev, Ivan Liprandi caught his friend Pushkin in the act of creation. The poet was unclothed, cross-legged on the couch, beating time, surrounded by little scraps of paper, which he then gleefully gathered up as soon as he realized he was being watched (145-46). This dervish-like image is of one piece with the poet-in-exile who appears in mixed company in transparent muslin trousers, no underlinen, and who challenges a casual acquaintance to a duel over the type of dance a provincial orchestra should play.

As we move through Binyon's book, an image of the poet comes together that is both more dissolute, and more miraculous, than we could have imagined. How, when did he manage to do it? Exasperated beyond all measure by Pushkin's swaggering bawdiness and by his readiness to call out even his close friends on some trivial pretext, Karamzin, Zhukovsky, and Vyazemsky emerge as bulwarks of sobriety and sane common sense. Tsar Nicholas himself intervened more than once on Pushkin's behalf against Faddei Bulgarin, urging the poet to ignore slanders cast at him, but Pushkin wouldn't hear of it. Even in a society where brilliant irregularities were 
celebrated, poetic genius revered, and a bourgeois work week unheard of, Pushkin's public self tried the limits of patience. Such was the daily behavior of the outer man. If the life of Pushkin's class and social set was all there was to how Russia was run - uninterrupted balls, receptions, dinners, duels, campaigns, card tables and love trysts - then Pushkin's world would have struck us as one huge masquerade along lines soon to be immortalized by the Marquis de Custine. But Binyon thickens the picture at crucial points, singling out institutions necessary to Pushkin economically and (in the broad sense) conceptually. These include censorship and police surveillance, literary publishing and marketing, foreign policy (especially the Polish uprising and the wars against the Ottomans), and the modus operandi of an aristocratic, serf-owning economy (debts and mortgages). Binyon's command of detail here is breathtaking, as is his deftly timed deployment of it.

Take, for example, debts. Binyon keeps a close eye on Pushkin's finances, and we are privy to the poet's account-keeping during those years when he cared deeply about his ability to provide. In early 1831, with his wedding imminent, on the debit side there were 24,800 rubles lost at cards (Pushkin insisted on paying these debts in full, even to cardsharps [337]); on the credit side, a hopeful 10,000 rubles for the publication of Boris Godunov and another 38,000 rubles from a 37-year mortgage taken out on 200 souls from Kistenevo, a village wondrously discovered to be unencumbered (353). By 1833 the picture was much grimmer. With his wife's expenses at court, a growing family, the large number of domestics desired by both husband and wife, and continuing gambling losses, Pushkin was obliged to weigh the liabilities and benefits of taking over the Boldino property in his own name (460ff). Half of its income went to pay interest on the debt. His wastrel father and idle brother had to be supported on the remainder. Pushkin, the sole creator of capital in the family, is revealed here as a strict, shrewd, no-nonsense manager of property, human as well as immobile. Ownership of Boldino would be worth the risk only if he could turn over to the government the sluggards and troublemakers among his serfs as a "recruit quittance," that is, as credit toward the draft quota. But despite his publishing ventures, the Tsar's bail-outs, and his modest subsidy as Historian Laureate, Pushkin could not make ends meet. This state of affairs severely strained his sense of honor.

In Pushkin's life, honor and its burdens accumulate gradually. At first, the poet acted like everyone else (his parents, his peers). He spent freely. He relished confrontation and public display. He took for granted his right to cuckold other men-even Count Mikhail Vorontsov, his immediate 
superior - while expressing horror that such a thing might happen to him. Attached as a civil servant to the Ministry of Foreign Affairs during his southern exile, he rejected the idea that any work should be asked of him at all: in Kishinev in 1821, to be sure, he was assigned one translation (137), but at a later point in his "service," when asked to gather information on locust damage in the field, he was enraged at the presumption on his time and autonomy (183). Pushkin appears at peace with his entitlements, if not with his fate.

With time, however, the poet's sense of honorable behavior became more nuanced and complex. At these delicate moments, Binyon reveals himself a master at narrative perspective. At times he reinforces Pushkin's worldview, causing us to wince alongside the poet trapped in his own white lie - as during the fiasco with the faked aneurysm in 1825, or the Gabrieliad incident in 1828 (where Pushkin denied authorship of the blasphemous poem to the investigating officials but felt obliged to reveal it to the tsar, resulting in deep personal humiliation, "which immeasurably strengthened Nicholas's hold over him" [282-83]). At other times Binyon's voice reflects the routine expectations of society or of the imperial bureaucracy. Thus we learn that in 1824 the locust epidemic was a serious matter; civil servants of higher rank than Pushkin had been given similar tasks; the poet was provided with money for expenses at three times the going rate, and even so he did not return the balance. By such mobility of perspective, Binyon creates an illusion of objectivity that does not exclude deep compassion. From the outside, Pushkin's reactions to events appear erratic, inconsistent, often uncoordinated. We see the poet dazzled by the image of the Emperor, dazzled by the greatness of Russia against the whining of the Poles, but in 1829, back from Arzrum, he refuses to produce the expected ode on the Turkish campaign - just as in 1826 he had refused to produce the reactionary pap on national education that Benckendorf believed was the government's due for having pardoned the poet (254). Through these vacillating gestures of resistance and compliance, the outline of a minimal acceptable honor slowly comes into focus.

The painful culmination of this balancing act comes with Pushkin's attempted resignation from imperial service in 1834, which Binyon reconstructs in excruciating detail (449-56). Once again the privacy of the poet's intimate correspondence has been violated. Pushkin writes in his diary, paraphrasing Lomonosov: "I will be a subject and even a slave, but not a chattel [kholop] or a jester [shut]." He submits his resignation to Benckendorf. Tsar Nicholas replies that he keeps no one in his service against 
his will, but that he would of course deny further access to the archives. The entire episode horrifies Zhukovsky, who browbeats Pushkin into withdrawing his resignation. Pushkin rethinks, sends a second letter with an apology, then a third letter confirming it. But the true revelation comes later. Zhukovsky, consummate courtier who is privy to all these missives, continues to be appalled: "You are out of your mind," he writes Pushkin; "you should order yourself a flogging to return you to your senses, don't you understand the Sovereign is grieved, he considers this to be ingratitude." Pushkin is puzzled. Like a self-respecting man, he asks Zhukovsky: "but how is this a crime or an ingratitude, when for the sake of the future of my family, personal circumstances, my peace of mind, I wish to retire to the country?" Zhukovsky (one senses through Binyon's cool prose) is at his wits' end. Does Pushkin really not get it? Must it be spelled out? What the poet has to do is grovel, for groveling is what will assuage the tsar's grief. But Pushkin does get it. It is precisely a chattel and a jester that the Sovereign desires as interlocutor, not a loyal servitor or (in Pushkin's fantasy-ideal) a great poet collaborating with a great tsar. And scandalously for Zhukovsky, Pushkin's sense of honor required that he have some say about how he would serve. But the parade grounds, ballrooms, and bureaucratic suites of Nicholas I's Russia were not the site for such relations. When the widowed Natalie insisted, to the Emperor's keen displeasure, that Pushkin be buried in his black frock coat and not his court uniform (631), she paid her fallen husband the most honorable final rites.

In the dynamics of this bungled resignation, I felt the beginning of the end for the poet. That line between subject/slave (acceptable to one's honor) and chattel/jester (unacceptable) could not be sustained. Perhaps Binyon would disagree, but from this point on in the story there seemed to be an upsurge of compassion for the Pushkins, which earlier had been in very short supply. Binyon is kind to and supportive of Natalia Nikolaevna. He presents her as a helpmeet as well as a trophy wife, a conscientious mother and good household manager, a woman with a head for finances - but whose extravagant tastes, alas, were shared fully by her husband. Although not immune to flattery, she did not lead her suitors on. D'Anthes disgusts Binyon (who nevertheless allots him a full and fascinating biography). He is weak, sentimental, frivolous, a darling of the court, a stalker and blackmailer (556-61). Husband and wife both do their best against such a phenomenon, but they are poorly equipped. Part of Binyon's closing strategy is to stress the normalcy of the final month (mid-December 1836 to mid-January 1837). The Pushkin melodrama has peaked; society is already talking of other things. All 
the more compelling, then, is the shock of that final furious challenge. When no one was looking, the unspeakable subtext erupted and suddenly became the text - and then the hero was dead, the crime hopelessly diffused.

Binyon's achievement is immense. Its limitations are intentional and self-imposed. But some reservations might still be raised. At times, Binyon goes too far to make Pushkin seem bad - or rather, to reduce him to his immediate impulses and perceived indignities. That the poet's appetites and exhibitionism might have been at least partly adopted for show is not seriously entertained. On the epigram war with Bulgarin, where both parties aim decidedly below the belt, Binyon remarks: "On reflection he [Pushkin] might have considered that it was neither edifying nor profitable" (319). Of course Pushkin did consider and reflect deeply on the issue. In an unpublished dialogue drafted in 1830, he gently mocks writers (that is, himself) who mistake an epigram for a refutation or an insolent exchange of wit for genuine criticism. ${ }^{2}$ But since Binyon has resolved to be true to the public image and public record of the poet, Pushkin's more moderate (and profoundly wise) private meditations are not given their due weight.

Then Binyon strikes me as borderline naïve about Pushkin's marriage and family life. Pushkin was certainly ambivalent about settling down, up until the final moment, and there is evidence that a part of him even wanted to be refused. He probably surprised himself with the ardor he felt for the novel roles of husband and father. But Binyon underestimates, I believe, the poet's astonishing power to remake himself for his own sake once a decision had been taken. "As with many men, the experience of fatherhood had a profound effect on Pushkin," Binyon writes (447), citing as evidence Pushkin's delightful, pious closing phrases in his letters to his wife, which bless her and the children and urge her toward more frequent prayer. Such a man, Binyon adds, would not take lessons in pure atheism or pen the Gabrieliad with a wholly clear conscience. About that it's hard to say; but the important point about Pushkin's marvelous letters to his wife seems to lie elsewhere. As Brian Horowitz has persuasively argued, the poet's spiritual self-fashioning in the early 1830s involved not only very hard work over a prose style, but also over a new identity for the professional writer (a

2 The dialogue was jotted down in 1830 in response to articles appearing in the journal Galatea. Pushkin's two interlocutors discuss the state of Russian criticism. 'A' remarks that "Pushkin even replies to his critics in epigrams. What more can you ask?" To which ' $\mathrm{B}$ ' replies: "But satire is not criticism - an epigram is not a refutation. I am working for the good of literature, not simply for my own personal satisfaction." 
sober, hardworking pater familias and domestic provider). ${ }^{3}$ Pushkin's letters home not only display him in that newly-fashioned role, but seem designed to induce his wife to "adopt the value system inherent in this new image." Reading his letters (as she did not read his poems), Natalia Nikolaevna would be educated in the virtues of domestic tranquility and the inviolate privacy of the hearth. This is not to suggest that Pushkin was deficient in love for his wife and children. But it is to suggest that when Pushkin changed, it was primarily in a literary-poetic direction, to increase his arsenal of creative resources - and those, as he well knew, were trans-historical and immortal. The family became an essential supporting muse. It was to prove more productive of mature spiritual growth than his earlier models of seducer, prophet in the wilderness, rebellious genius, or wandering Byronic poet. Since Binyon sticks so close to the marrow of the present and resists any move toward mythologization, Pushkin's efforts at zhiznetvorchestvo - at creating one's life as a work of art and for the sake of art - can only be a minor theme.

Finally, there is Binyon's overall ethical intonation. Does he approve of the story he tells? He would like this question not to matter. His strategy is to let the "facts speak for themselves." But a fact has many faces and a documentary is never innocent. If the compiler declines to intercede for the historical subject, even the most objective documents can easily default to value systems operative in the reader's own present. Consider one easily quantifiable theme running throughout the biography: financial indebtedness. Binyon presents the sums straightforwardly. Yet he does not go out of his way to explain that a gentleman's indebtedness meant something different in the 1820s and 1830s than in successive bourgeois eras more familiar to us. Within certain limits the more debts a man could carry, the better his word of honor was considered to be. Binyon is no sociologist. He simply describes, which risks conflating moral reflexes natural to us today with those native to Pushkin's time. In the mode of great detective writing, a sense of the present is kept vibrantly alive throughout. To an unprecedented extent we feel that we know and can touch the vulnerable man. But the costs of this palpability are real. To achieve a shared present, Binyon, for all the brilliance of his period detail, is prone to transpose Pushkin forward into our time rather than attune us backward, to the socio-ethical realities of the Romantic era.

3 Brian Horowitz, “A. S. Pushkin's Self-Projection in the 1830s: 'Letters to His Wife,", in Pushkin Review / Pushkinskii vestnik 3 (2000): 65-80. Subsequent quotation on p. 66. 


\section{The inner man (Pushkin through Surat/Bocharov)}

If Binyon presents us with the social imprint of the outer man, then the strategy of Irina Surat and Sergei Bocharov is its polar opposite. They begin with the internal - and the eternal. Their volume, we learn, is the result of an encyclopedia entry that outgrew its genre boundaries (7). Traces of the original rubric remain in the opening and closing lines: "PUSHKIN Aleksandr Sergeevich [26.5 (6.6) 1799, Moscow — 29.1 (10.2) 1837, Petersburg] — poet. Father - Sergei Lvovich"; then, two hundred pages later, "on 29 January at 2:45 p.m. he passed away." Unlike Binyon, who provides an Epilogue on the fate of Pushkin's writings, wife, children, and nemesis D'Anthes, Surat/ Bocharov remain strictly within the consciousness of their subject. There is something thrilling about this encyclopedia frame. It lends an authoritative dryness to the famous profile, yet celebrates (as encyclopedias are designed to do) the canonized, memorialized status of the subject.

Everywhere the authors display exceptional tact. Where Binyon gives us Pushkin at his most provocative, relishing scandals and even setting them up, Surat/Bocharov are non-committal and nonjudgmental. Their verb of choice for outrageous situations is oslozhniat'sia. Awkward, inconstant moments in the poet's life are moments that have "become complicated." When the liberationist rhetoric of Pushkin's early poems or his apparent sympathy for the insurrectional Greeks appears to contradict the pride that Pushkin takes in imperial bayonets aimed against the freedom-loving tribes of the Caucasus, resolution is matter-of-fact: "Thus was born and gradually matured in Pushkin's consciousness a complex collision between empire and freedom" (33). Such inconsistencies are not presented as irresponsible; they are conceptually and morally productive. They trigger in Pushkin a deeper appreciation of history, and especially of the paradoxical Peter the Great, both autocrat-tyrant and revolutionary. The seduction of Elizaveta Vorontsova in Odessa is evaluated first for the splendid love lyrics and graphics it produces (a half-dozen poems and over thirty sketches); only then do we read that the love affair "complicated Pushkin's personal and service relationship with her husband" (40). Nothing about the rumor of Vorontsova's swarthy infant daughter perhaps being Pushkin's child; and nothing about Count Vorontsov's indifference to his wife's infidelity, which freed the General for his own mistresses and greatly irritated Pushkin, a man at home with scandal but who despised being patronized against his will (Binyon 177-78).

What is "experimental" about this reverent co-authored biography is at first obscure, but soon becomes clear. Details of the outer life that others see 
are to be measured solely by their inner literary fruit. If the most serviceable verb is "to become complicated," then a favored modifier throughout is dushevnyi, that untranslatable space between the spirit and the conscious mind where all creativity begins. What happens to Pushkin "on the outside" is of interest, of course, and will work to simplify or complicate his life, but the fulcrum around which all value revolves is the poet's own inner sense of his genius and his concomitant obligation to generate the poetic word. Relations between external event and the internal imperative to create are two-way and reciprocal. The poet writes "Vol'nost'" at a time when his own political convictions are not fixed ("at that moment, Pushkin simply didn't have any" [20-21]); the ideas it contains are the banal, clichéd formulas of the French Enlightenment. But these familiar sentiments prove freshly dangerous because "Pushkin was above all a poet, and from his pen political ideas received such public poetic strength as the radical minds that had given birth to them could only dream of" (20). It is the arousing power of poetry, not of politics, that makes for revolution. Thus Pushkin the poet is exiled and put under surveillance, not for any radical sympathies or madcap deeds (indiscretions that in Binyon have pride of place) but precisely, exclusively, for his words. This dialectic between word and deed is laid out in the prefatory note "from the Authors": "A poet is a special creature, he does not live like everyone else. He doubles his life with his word, he encloses it in the word, and the word becomes his fate" (7-8).

It is no surprise that the authors take seriously Pushkin's 1819 encounter with the German fortune-teller in Petersburg - not because her precaution was accurate (such privileged speech is hard to disconfirm), but because Pushkin all his life believed in it. By the spring of 1835, he had even come to feel that the "moment for fulfilling the prophecy was drawing nigh" (191). But one's fate, sud'ba, must be understood in Pushkin's sense, which was that of the ancient Greeks. Sud'ba is not superstition, not providence, not an end-point. It is a dynamic. To know your fate is not to fall passive before it; constant struggle is required to realize your fate in the proper, honorable way. Chance occurrences continually clutter the path. Pushkin "did not live like everyone else" in part because he grasped the shape of this struggle. At the beginning of his southern exile, Pushkin already "had begun to see the outline of his fate" (24) - and was devising means for surviving it and turning its unfreedom into creativity.

Scattered along this trajectory are many deft capsule readings of individual works. Ruslan and Liudmila startled its first readership as a "humorously modernized image of Ancient Rus'," in which pious motifs were profanely 
lowered (21); The Gypsies bore a trace of the poet's skeptical encounter with Rousseau (43-45). Much is made of Pushkin's curiosity, beginning in 1826, toward sacred texts from exotic, non-Russian cultures. Glinting through the narrative are moments of keen insight on the psychology of the lyric and the ironized prose consciousness of Evgeny Onegin, recalling Surat's impressive cycle of Pushkin studies from the 1990s and Bocharov's preeminence as a disciple of Bakhtin. But it is as an experimental "sketch of the life" that this biography is most distinctive. The authors divide it into three segments: Lycée-Mikhailovskoe (1811-1826), Mikhailovskoe-Boldino (1826-1830), and "The Thirties." Each segment ends on a spiritual threshold requiring the poet to define himself anew, in a more risk-laden way. This new definition is then tested, stripped of its illusions, and embodied in poetic masterpieces. Up through 1826, the life is governed by the poem "Prorok" (71). The threshold achieved is the confluence of two contradictory Decembrist themes: the gallows (for his friends) and mercy (for himself). The middle section opens on Pushkin's audience with Tsar Nicholas, a "pivotal moment in his biography" (74) because the highest authority, it now seemed, sought his advice and ideas: to his role of prophet Pushkin has added sovetnik tsaria, "councilor to the tsar." The rapturous autumn of 1826 marks the end of his rebellious youth. But unhappily, it was not the hoped-for beginning of an imperial service worthy of his genius.

By 1830 Pushkin had resolved to redirect his energies. His bachelor life, his Onegin, his love lyrics and on-the-road verse now give way to a pursuit of stability and the family hearth, reflected in a turn to the Russian past, to prose, and to a "poetry of reality" and thought (123). This new sobriety burdens the poet with new obligations: to prophet and would-be advisor to power is added the poet as witness to history. Pushkin's travels in Pugachev country, his interviews with survivors of the rebellion, and his impulsive attempt to participate in military action during the Arzrum campaign are all testimony to the ambitions of this new voice. Among the fascinating details of this self-fashioning trajectory are the works that Pushkin chose not to create, in keeping with his sense of his fate. In 1824-25 he wrote an elegy to André Chenier and not (as everyone expected he would) to Lord Byron (55); in 1836 he confirmed his earlier refusal to produce an ode on Russian military victory by transforming his Arzrum travel notes into a wryly deflated reminiscence (186-88).

To be sure, this conventional tripartite division of the life obscures some works. The 1825 Boris Godunov, for example, composed six years before the poet's prescribed turn to history, risks being read more for its innovative 
dramatic form than for its superbly well-informed historical grasp of that pivotal reign. But on one point, Surat/Bocharov are refreshingly post-Soviet. Throughout the 1830s, their Pushkin doggedly pursues ways to serve the Emperor with honor. He stubbornly nourishes his desire to see in Nicholas I the reforming potential of Peter the Great. Only with the second Boldino autumn, 1833, does disillusionment (or revelation) descend irreversibly, as evidenced by the endings of Angelo and The Captain's Daughter: their fairy-tale resolutions come to pass solely through arbitrary acts of mercy, not through honest dealings under law (151). The justice awarded Pyotr Grinev - "a simple man in very complicated circumstances out of which he emerges with honor, again and again" (175-76) — is available to him because he is as fearless, faithful, and truthful as a folklore hero. But his survival is an accident and a miracle.

Such utopian motifs are as far as Surat/Bocharov will go in documenting Pushkin's growing entrapment and despair. But even despair, we are given to believe, registers on Pushkin differently than on ordinary people. Professional humiliation leads to an inner resignation that is also harnessed to the muse, giving rise to the apocalyptic, pagan, and Christian themes in the final poems. Although Pushkin hoped that his journal Sovremennik would permit him service with honor (and an income as well), still, he resolutely went forward to realize his fate; during the final two years, "dramatic outer conditions [...] were complicated by an acute need for inner self-orientation in premonition of the end" (193). Debts mount, sales of his works are poor, harassment intensifies, but these disasters are presented very abstractly; whatever responsibility the extravagant Pushkin might bear for them is morally invisible.

The biography postpones until the last possible moment any mention of D'Anthes. If Binyon's Pushkin tumbles toward his end, Surat/Bocharov's prophet-poet sees it, prepares for it, is fueled creatively by it, and awaits the trials that D'Anthes (an arbitrary carrier of fate) will place in his path. A more serious omen than this trivial officer of the Guard is the fruitless autumn of 1835, which deeply depressed the poet, and the lyrics on madness. Surat/Bocharov pay scant attention to the marriage, its joys or its anguish. Whereas Binyon makes Pushkin's quest for a wife a focal point from 1826 on, there is almost no comment here on this huge shift in the poet's daily life and responsibilities - beyond the dom/penaty/hearth theme in the poetry. Only two of the couple's four children are graced with a birth notice. Thirteen pages before the end (207), D'Anthes makes his appearance, but his pursuit of Natalia Nikolaevna is diluted immediately with three other unnecessary 
duels that Pushkin provoked in the early winter of 1837. Tucked in after a detailed discussion of the Stone Island cycle is another mention of the Frenchman renewing his suit (215). But an integrated view of the final months is ventured only on the penultimate page.

Surat/Bocharov would like to dismantle the myth of Pushkin's overreaction to the fatal anonymous letter. The poet, they insist, knew what was at stake. His increasingly inflammatory responses to this provocation were necessary "to affirm publicly the truth about himself and his family life, to preserve his name unsullied, which, he knew, already belonged to history" (218). His fury was "an act of full liberation from society" (218), a declaration of independence from all that had not answered to his high hopes for the calling of a poet. But it was more: "The inner starting point of the final duel was the contrast between the intrigues, the floods of slander and filth inundating the Pushkin home, and the image of authentic existence toward which he had been striving during the final years" (219). By this point in the biography, everything has become inner. What the outside world happens to see has little status as evidence. If Binyon's Pushkin in his final months is a bit of a bore and a laughingstock, a gifted man harassed out of his mind but too stubborn to follow the sensible advice of his friends, then Surat/Bocharov's is a tragic hero, for whom every life-move had been an investment and for whom pursuit of "authentic existence" is dissociated from personal behavior. No significant thing, it would seem, is ever Pushkin's fault. Both versions of the life must agree, of course, on the peerless courage and stoicism of the final two days.

How do these two profoundly dissimilar biographies measure against one another? Surat/Bocharov is firmly in the Russian (and Romantic) tradition of maximal reverence toward the poet, not only as a privileged consciousness but also as a human being set apart, exempt from judgment, who acts as he does in order to write what he must write. Within that tradition, these two authors represent a specifically "Moscow" methodology, more spiritual and speculative than the textologists of St. Petersburg's Pushkinskii Dom. ${ }^{4}$ One palpable predecessor for Surat/Bocharov's project is Yury Lotman's graceful biographical classic from 1981 (although their co-authored image is far less athletic than his). Lotman too presents the poet as a sort of alchemist who intuitively turns

4 For an excellent discussion of these two Russian schools (and of foundational Pushkinistics in general), see David M. Bethea, "Introduction: Of Pushkin and Pushkinists," in The Pushkin Handbook, ed. David M. Bethea (Madison: University of Wisconsin Press, 2005), xvii-xlii. 
every misfortune into precious metal. In contrast to this Russian model, Binyon, following a more secular and demystified Western pattern, gives us a Realistic - or perhaps an acidic and satiric eighteenth-century - picture of the poet on the ground, a person who must answer for his deeds like everyone else. In this profane tradition, "real" often means ugly, low, the comedy of life viewed close-up. As a result, the same facts feel utterly different in the two biographies. When Surat and Bocharov remark that Pushkin's lyrics affirm a "cult of immediate sensual pleasures" [kul't siiuminutnykh naslazhdenii] (18), it sounds more like a philosophical position than an appetite. Binyon simply shows us a vital man grabbing for what he loves.

But here is the remarkable thing. Binyon's Pushkin - so full of lust, rage, hunger, error, curiosity, a profligate in life - seems somehow happier and more real than the Russians' image. In Surat/Bocharov, Pushkin's life is one long taking-on of obligations and burdens: prophet, councilor, witness to history, martyr. The poet desires to do and to be all this, of course, but we sense in this image little zest for the actual experience of living. Pushkin looks around, sees an inadequate world, sighs, and sets to work. Emblematic is the end of the 1820s, when Pushkin seriously begins to tackle prose. "The shaping of Russian prose," we read, "turned up on his creative path as a national task"; and "this obligation too he took upon himself" (97). Readers will differ, but to my ear this constant undertone of martyred duty muffles the most precious ingredients in Pushkin's life. With Binyon - and forget that he does not analyze the poems - we are on the edge of our seats, always wondering when this madcap will find the time to create his masterpieces; with Surat/ Bocharov, never. Read in tandem with Binyon, the Russian way stands out in sharp relief. While appreciating playful enthusiasts such as their own Andrei Sinyavsky, Russian academics will most likely continue to find their comfort in biographical modes more hagiographical than the Tolstoyan-style razoblachenie, "expose and embarrass the subject," that wins prizes in the West.

\section{The perishable things of Pushkin's world (Tyrkova-Williams and thick description)}

The third volume under review - longer than both the preceding books combined-adopts a composite methodology, both romantic and naturalistic. Its author was an amateur. In the Herzen and D. S. Mirsky mode of Russian émigrés in London, Ariadna Tyrkova-Williams was as political as both but far less enamored of the socialist experiment. She embarked on 
her Pushkin biography in the early 1920s, in part to recuperate what she knew was lost forever. This sense of absolute loss dictated her special type of nostalgia: precise, thick, objective, unsentimental. The appearance in 1929 of Volume 1 of Zhizn' Pushkina (covering 1799-1824) was met with polite silence from professional émigré Pushkinists such as Vladislav Khodasevich and Modest Gofman; both volumes, however, were eventually well received in the general press as narodnaia biografiia, a "popular/people's/national biography" of the poet. Its reprinting in the late 1990s and then in 2002 in the series "The Life of Remarkable People," with a lengthy introduction about the author, marks the welcome return of a prominent anti-Bolshevik to post-Communist Russian culture.

"For me the biography of Pushkin is a school, and a revelation, and relaxation, and an inexhaustible resource of the Russian spirit," TyrkovaWilliams wrote to her son Arkady in Paris in April 1927. "I began to think about it in January 1918, at a time of pitch-black grief and despair. Many years have passed since that time, and I have succeeded in doing little. But if I succeed, it will be a genuine 'white deed.' A source of faith in Russia." ${ }^{5}$ By then she was 57 years old and settled permanently in England. Little in her tempestuous prior life would seem to explain this passion. Ariadna Tyrkova was born into an ancient Novgorod merchant family in 1869 and raised, with her six siblings, in the radical-intelligentsial spirit of the 1860s. Her brother Arkady was exiled to Siberia in 1881 in connection with the assassination of Tsar Alexander II; young Dina, just into her teens, was expelled from the gimnaziia (where she had befriended Nadezhda Krupskaya). In 1888 Ariadna enrolled in the Higher Course for Women and married a maritime engineer. In the mid 1890s - divorced, with two children to support - she began working as a journalist under a male pseudonym for various provincial newspapers in Yaroslavl and Ekaterinoslav, providing feuilletons, reviews, news summaries, and fictional sketches. Her first literary skills, then, were acquired in the Chekhovian manner, as a livelihood and not as a leisurely aesthetic pursuit. Key to her writing was a keen eye for detail, setting, and a talent for evoking sympathy with the well-focused human scene.

$5 \quad$ Oleg Mikhailov, “'Dva chuvstva divno blizki nam...' (Ob A. V. Tyrkova-Vil'iams)," in Ariadna Tyrkova-Vil'iams, Zhizn' Pushkina (Moscow: Molodaia gvardiia, 2002), 1:7-26, esp. 21. The biographical summary given here is indebted to Mikhailov's account and also to Alexandra Smith, who, in person and in her writings, introduced me to this unusual émigré project. See Aleksandra Smit, "Formirovanie literaturnogo kanona v knige Ariadny Tyrkovoi-Vil'iams 'Zhizn' Pushkina," in Pushkinskie chteniia v Tartu 2 (Tartu: Tartuskii universitet, 2000): 267-81. 
By the turn of the century, Tyrkova was known to the leading revolutionary activists (as she later remarked, "the three founders of Russian Marxism were married to my school friends" (10)). Influenced by Gorky, Artsybashev, Andreyev, and Briusov, her own politics grew more radical. In the first revolutionary period (1903-05) she was twice arrested; faced with a twoand-a-half year prison term, she decided to flee abroad. In Stuttgart she met the Englishman Harold Williams, left-leaning correspondent for the Times, who became her life's companion. In Geneva, visiting her friend Krupskaya, she first encountered Lenin (who made an intensely negative impression). More significantly, she met Peter Struve, from whom she received her first systematic political education. Tyrkova's career as a Constitutional Democrat began. Rising quickly in the party, she led the Kadets in the State Duma, 1906-07, and by 1912-13 was covering Duma events for various Petersburg papers. As editor of Russkaya molva, she recruited Aleksandr Blok for her columns. She and Williams hosted literary evenings in their large Petersburg apartment where, she recalled, "everyone was there but Mayakovsky" (15).

A half-century later she remembered this stressful, hopeful period between the Vyborg Manifesto and Kerensky's brief regime as one uninterrupted attempt to shore up the illusion of a potentially liberal Russia. Throughout 1916, Tyrkova-Williams represented the Kadet Party (loyal to the government and the war effort) in the Petrograd City Duma. In January 1918 she spent some time in the Rumyantsev Museum in Moscow, acquainting herself with Pushkin's manuscripts. This glimpse would become precious to her later, when, as an émigrée in London, she would have access to scholarship from both the exile community and the Soviet Union - but by then, Soviet interpretations of the manuscripts were ideologically constrained. Tyrkova never disdained the fine textological work produced by official Soviet-era Pushkinists in the 1920s-40s, but also never ceased to plead for the full publication of all extant manuscripts - the prime necessary resource, she insisted, for any literary biographer. ${ }^{6}$ By March 1918, threatened with arrest, Tyrkova moved with her husband to England.

$6 \quad$ See the author's Preface to Volume 1 (1928): “Up to the present day neither the private publishing houses, nor the Academy of Sciences, nor Pushkinskii Dom have published the whole of Pushkin in all its completeness. In Russia, despite all catastrophes and shocks, a cult of Pushkin has been created and continues to grow. Pushkiniana is immense. But no one has published everything from his hand, all that was written, rewritten, marked up, crossed out, struck out... not knowing all the variants, how can one investigate the birth and movement of the verses? His poetry and his character, his work on a manuscript and his work on himself [... ] are so fused that it is impossible to dissociate them" (30). 
Attempts to raise an anti-Bolshevik alarm on British soil were not successful. In October 1919, Tyrkova returned to Rostov-on-the-Don (then held by Denikin's Whites) and soon after to Kharkov, for a Kadet congress (the party's last). Narrowly escaping by ship from Novorossiisk, she made it back to England; miraculously, her mother and children were also safely evacuated. Beginning in 1922, the Williams home in London became a haven for visiting Russians of the first emigration (their guests included Remizov, Bunin, Zaitsev, Tsvetaeva). In this cultured environment, in her early fifties, surrounded by family and by her own admission at the happiest, most secure time of her life, Tyrkova began writing her biography of Pushkin. She was fortunate in her resources. The British Museum was nearby, as was the London Library with its Ostafiev archive and Russophile director. The first volume of Zhizn' Pushkina was completed in 1928. In that year Harold Williams died, and his widow interrupted her Pushkin labors to write his biography. Only in 1935, at age 67, did she return to her Russian subject - whom she had left stranded, she wrote her son Arkady, in the wilderness of Darial. Volume 2 was finished in time for the Jubilee year 1937. Tyrkova brought the manuscript with her to Paris (where Volume 1 had been published) in May 1940. The timing could not have been worse. Paris fell. Throughout the occupation, Tyrkova and her son were trapped in the south of France, in wretched quarters near Grenoble. In 1948 Volume 2 finally appeared. Soon after, Tyrkova and Arkady emigrated to the United States, where she died in 1962, in her ninety-third year.

What are we to make of this 950-page project, written by a contemporary of Chekhov's over a period of thirty years, which is only finding its readership now, in the early twenty-first century? Tyrkova-Williams was better equipped for the task than it might at first appear. Unlike many academic Pushkinists in her native country, she had practical political experience - and of the answerable, parliamentary sort. She was not repelled by the prospect of important people, even poets, cooperating with state power, nor by the need for pragmatic compromise. She was also an experienced journalist with an ear for alien voices and an excellent sense of place. Her biography of Pushkin, while not thickly or precisely footnoted, is saturated with excerpts from memoirs, letters, and popular legend, always apt if at times vaguely tagged ("Annenkov," "Pushchin," "Rasskaz Ia. N. Tolstogo"). For all its bibliographical casualness, this is not a biographical novel. As the third of our texts under review, it adds an ambitious new dimension.

Binyon emphasizes how Pushkin looked and sounded to others; Surat/ Bocharov, how Pushkin looked and sounded to himself. Tyrkova-Williams 
attends primarily to how the world looked and sounded to Pushkin - and why his reactions to that world were reasonable, given those impressions and pressures. For a vital component of émigré recuperation projects was to capture a disappearing world, not only to register a poet's alchemy on that world. Tyrkova works by thick description. The confirmation of facts or the correction of errors in earlier accounts - a telltale impulse separating the academic professional from the amateur — is not her purpose; her ideal reader is the common one, perhaps a newspaper audience, curious, naïve, a person who can be drawn in with startling indicators of a world positively different than our own. On those rare occasions when she does engage the Pushkin Industry, it serves her larger vision of the poet as a political liberal. One such moment is her lengthy interpretive gloss on the shut / tut controversy (p. 38 of the 1826 Mikhailovskoe Notebook \#2368, embellished with gallows and five hanging bodies). Should we decipher Pushkin's handwriting here as "and like a fool [shut] I could have been ..." or "I too could have been there [tut]"? Tyrkova insists on shut, relying on her examination of the manuscripts in 1918 (2: 136-37). But she enters this quarrel at all, it seems, largely because scholars in Stalinist Russia were now obliged to confirm the opposite as regards Pushkin's revolutionary Decembrist sympathies.

As we have seen, building a scene from the bottom up is also Binyon's way. But since his goal is to demystify the poet and free his image from its pious straightjacket, his details tend to debunk and abrade. Tyrkova rarely moves against the Pushkin Cult in that aggressive way. On the contrary, she is more prone to interrupt her realistic inventory with a passage of high Romantic pathos - reminding us of the East-West biographical divide, and locating her hybrid émigré narrative squarely between Binyon and the Surat/ Bocharov model. A case in point is Chapter 3 (1: 66-78), introducing the Lycée years. First the school is placed in an all-European perspective (its advanced pedagogy from La Harpe, its unprecedented exclusion of corporal punishment), then a Russian one (only eight years earlier, it had been decreed that foreign as well as native professors throughout the Empire conduct their classes in Russian; thus a technical lexicon was still lacking for many classroom subjects). Details of the inauguration ceremony, the architecture of the school, the changing color scheme for student uniforms, the approved diet and drinking code, the daily schedule (from 6:00 a.m. to 10 p.m. with an unusually high number of breaks for progulki [nature walks]), and the multifaceted curriculum are followed by a catalogue of personnel (directors and professors). Finally we meet the Lycéeists themselves: a gifted, rowdy bunch of boys with a high sense of entitlement. At their core, but not 
yet in the spotlight, is twelve-year-old Pushkin - getting on with some teachers, not with others, and finding the strict daily routine a relief from the disordered household he had left behind. (Habits formed here would prove durable: early morning work time remained the poet's practice until the end.) But then suddenly this glittering reconstruction fast-forwards to the fully grown myth, worthy of Surat/Bocharov and laying bare the larger rationale for Tyrkova's fine-grained contextualization: "And most important: not suspecting that among them there was one chosen by the gods, that their Lycée life was lit up by the light of his genius, that thanks to Pushkin all details, trifles, foolishness of that entering class would be preserved in the memory of Russian people for many long years, and would become the special mark of Russian history" (69). She's right, of course. Would she have bothered to track down all that colorful and meticulous detail if Pushkin had not emerged from it?

These occasional ecstatic inserts, interrupting and justifying a narrative otherwise glued to its own time, release Tyrkova-Williams from the need to pass judgment on individual actions. A sense of causality and responsibility emerges that is quite distinct from that achieved in the other two biographies. First, like a feuilletonist or ocherkist, Tyrkova sketches in the world; only then (so the logic of this genre goes) might a reader later hope to approximate what felt normal for a biographical subject of that world. The strategy is apparent from the opening chapters, "The Past" and "Sashka" (1:32-63). Information is given initially in visual images, textures, sounds. "Pushkin was born [...] on the threshold of two centuries," begins the biography. "Around his cradle stood people in powdered wigs" (32). These eighteenthcentury wigs then become the minor instance, the civilized anomaly in a Moscow where cockfights and fisticuffs are standard street entertainment, where physical danger is everywhere the norm, where twenty-five miles from the city the untamed frontier already begins and the larger estate-owners routinely arm a portion of their serfs (out of rivalry or boredom, these serf militias would often do battle with one another), where domestic violence is wholly unmarked (fathers whipped their grown sons). Only after this general background picture has been sketched in do we learn that "Pushkin's family was too enlightened for the savage practices of serfdom," preferring the "freedom-loving French spirit." But this spirit too requires qualification. "The Pushkins were insufficiently serious to have matured into humanism, but they were Voltaireans, which introduced a certain restraint into their gentry habits" (35). Tyrkova-Williams, a well-traveled intelligentka-journalist from the provinces who was born only three decades after Pushkin's death, 
surely knew what sort of behavior could be expected of such generations in such environments.

In between these two poles - Moscow the violent village, and Voltaire Pushkin's childhood unfolds. The same fused extremes are noted in his ancestry: Gannibalovshchina, patriarchal rage, coexists with a 400-volume library that its owner hauled intact all over Russia. Pushkin's mother, "La Belle Creole" with her yellow palms, is the capricious female variant: pampered, lacquered, exhausted by pregnancies (eight children, of whom five died in infancy), impossible to please. Maternal grandmother and beloved nurse provide whatever nurturing there is, and an introduction to Russian history as well (Maria Alekseyevna's small property of Zakharovo once belonged to Boris Godunov). But Tyrkova never fails to point out where, in the cracks of parental virtue, seeds of their elder son's calling might have taken root. Nadezhda Osipovna knew the social value of a smooth French exterior and made certain her two surviving sons acquired it. Father and uncle were of course inadequate mentors, but their best was still not a bad place to start for a precocious child with a keen memory. Little Sashka absorbed their wicked wit, skill at repartee, drawing-room theatricals and bawdy humor that would pass without warning into morose pouting or rage. When rage struck (the elder Pushkins were known to slap their children in front of guests), there was always the refuge of the library. "All in all," Tyrkova concludes, "Pushkin was not an unhappy child" (60). He was not guided, but also he was not stifled, and this very porousness allowed him considerable rein. In salon and library, he learned a great deal that should have been hidden. And when he left for the Lycée, he did not look back.

Tyrkova's placid texture and cool explanatory tone recalls more Turgenev or Chekhov than it does hagiography or Tolstoy. Undergirding it is the assumption that people, and especially extraordinary people, are not heroes as much as survivors and optimizers of circumstance. Their life-strivings and potentials take shape around what feels possible, comfortable, normal, worth trying out within those circumstances. Thus must Tyrkova spend so many pages setting up palpable surroundings. She employs the same technique with every new space Pushkin enters: the Caucasus and Crimea (1:345ff), Kishinev (1:288ff), Mikhailovskoe (2:89ff). First she sketches its history, then its flora and fauna, its roads and restaurants, its local entertainments and curiosities. This technique brings her close to Binyon - except Binyon tends to fill in human stories; Tyrkova-Williams emphasizes geographical and institutional ones. Pushkin's world is set in motion as a confluence of environmental conditions. Neither fate nor willfulness has a defining role. It becomes as difficult to reproach Pushkin as to deify him. 
Take, for example, Karamzin and Zhukovsky. Binyon presents both as wise counselors, respecting Pushkin's gift but reprimanding the man. Surat and Bocharov admire these two courtiers as adorers of poetry. Tyrkova is less impressed. Although she quotes Zhukovsky's letter to Pushkin of November 1824 ("To all that has happened to you and that you have brought on yourself, I have one answer: Poetry [...]"), she shrugs off its stoic eloquence, noting only that Zhukovsky "did not hurry to answer the poet's desperate letters" (2:13). In Chapter 13, titled "Tverdyi Karamzin" [tough-minded / firm Karamzin], she acknowledges that the historian was intensely irritated by Pushkin's "wild living, mocking tone, Voltaireanism" (1:184) but also that the older man was dry and severe with the poet, "did not like him, and did not trust his moral authenticity" (1:233). Tyrkova sees nothing irregular in Pushkin's affair with Eliza Vorontsova. In her chapter "David and Goliath" (1:416-26), we learn of General Vorontsov's hypocrisies and disrespect for Pushkin, the impudence of Alexander Raevsky (who dared to court Eliza as well), and then the dastardly final blow: Vorontsov actually assigned Pushkin an official task (the infamous inspection tour of locust damage, Chapter 35, "Sarancha").

These locusts are a useful focal point. In Binyon, we recall, this incident is narrated in a bureaucratic voice zone (181-82): a reprimand is in order, for an absolutely idle salaried official was shirking his duties. Binyon dismisses as disingenuous and less than honest the letter that the "horror-struck" Pushkin wrote in his own defense to the Odessa official Kaznacheyev, in which he defends his trade as a full-time poet and explains his salary-for-no-work as compensation for being denied access to the book markets of the capitals. Binyon insists that this was fantasy: however unjust his exile, at that point in his life Pushkin had never dreamed he could live by his pen. His first royalties (for The Fountain of Bakhchisarai) had arrived only the previous March and had taken him quite by surprise. And after receiving that bonanza, Pushkin "became even more outrageous in his behaviour" (179). Tyrkova-Williams, not averse to a retrospective view at threshold moments, contextualizes the event quite differently. Pushkin's honorarium was the first such paid to any Russian writer, and it "opened a new epoch in Russian literature; [this was ] a triumph for all writers, for the entire intelligentsia just being born," whose task it was to create a self-respecting "industry of the mind" (1:387). She interprets the letter that Pushkin was obliged to write to Kaznacheyev as a historically symbolic act, "one stage in the agonizing, years-long correspondence of a great poet with bureaucrats who did not understand that poets too serve the Motherland and the state" (1:448). This struggle 
becomes emblematic of the crippled state of Russian civic society. Indeed, the highest compliment Tyrkova can pay a government official is to call him a "humanist," that is, a person who instinctively protects individuality and creativity from the caprice of power. (General I. N. Inzov, Pushkin's indulgent supervisor in Kishinev, is described as one such "typical Russian humanist of the eighteenth century" [1:289]). There are moments when even Alexander I seems to qualify for the epithet. Tyrkova speculates that the tsar's heart must have thrilled - albeit illicitly - when he heard the dangerous ideas of his own youth, inevitably proclaimed during that era in stiff rhetorical French, take harmonious wing in Russian for the first time in "Vol'nost'," an ode composed by a poet scarcely graduated from the school bench (1:221).

No biography of Pushkin can forego discussion of "Poet and Tsar." Tyrkova's chapter under that title (2, ch. 9) focuses on Pushkin's premiere audience with Nicholas I in September 1826, a much-mythologized event. She is remarkably even-handed. Among her repeating motifs is that the time-honored Russian standoff between literary words and state power has been miscast; the line of hostilities should be drawn not between "Poet and Tsar" but between "Poet and Bureaucrat" [poet $i$ chinovnik]. Although Tyrkova resembles our other biographers in her attention to Pushkin's quest for service with honor, her angle of vision is far more subtly adapted to the expectations and circumstances governing all major players, not just Pushkin, and she sympathetically reflects what would feel normal for each. In this quest, it turns out, poet and tsar are equally powerful, needy, anxious, and flawed.

Tyrkova presents Pushkin before 1820 as an almost unqualified winner. In verse-making he was the awe of the capitals. In lovemaking he was a "born Don Juan" (1:186), the envy of his far handsomer friends. In pride of nation, he was at one with his class and his era: serious Shishkovian and comic Arzamassian each loved Russia in his own way, and the "authentic patriotism" of both was never in doubt (1:119). But if love of country was taken for granted by Pushkin's generation, service to one's country, including a personal identity achieved through the daily fulfillment of duties, was a more stressed matter.

Service had not been the norm in the childhood of the poet. Both parents "had spent their entire lives in prazdnost' [unfettered freedom, holiday time, "dutylessness"], with no concept of the conditions required for work" (2:11). The structured life of the Lycée provided a wondrous counter-model. But Tyrkova suggests that Pushkin did not seriously consider the problem of 
service until the first year of his southern exile, while traveling with the Raevsky family. He was discomfited, unable to press his suit with Maria Raevskaya, and embarrassed by a lack of funds. In a chapter intriguingly titled "Robkii Pushkin" (1, ch. 20), Tyrkova traces the poet's timidity to his intimacy with that glittering family of military servitors. Shtatskii Pushkin, Pushkin the Civilian, is a major theme throughout Volume 1 . The stage is set in the opening pages, where the Alexandrian epoch is described as an era when everybody fought all the time, "east, west, north [...], in jest, in mischief, in swashbuckling, in duels, and sometimes simply in brawls" (1:34). "Civilian Pushkin lived among military men," Tyrkova writes (1:29697); "[he ...] completely shared the conviction of his military friends that one's honor must be defended with a weapon in one's hands." With no contradiction, then, the poet could admire a "defense of honor" by rebel Greeks against the Turks, by Russian bayonets in the Caucasus, and - in his own personal life - by those unnecessarily provoked duels in Kishinev. The common denominator in each instance was not freedom, but honor. Belligerency was a primary ingredient in friendship, courtship, and service. "At the beginning of the nineteenth century," she assures us, "military service was not an external duty but a matter of conscience and honor" (361).

For this reason, civilian Pushkin - proud, even morbidly proud, of his ancestors in the service nobility - was uncertain how to define his role. It would not be by assessing locust damage, of that he was sure. But neither would he produce celebratory odes on demand. If poetry was his trade [remeslo], then it too could produce wealth, self-sufficiency, and conditions that enabled honor. But financial autonomy gained by honorable employment was only one aspect of Pushkin's mature understanding of service. The other was his concept of izbranniki sud'by, "those chosen by fate" (the title of Chapter 27 in Volume 1) - a category, it appears, that could apply to a tsar, a rebel, and a poet. Chosen tsar and chosen poet obligate one another mutually. For all that the initial audience between them was "staged with Napoleonic theatricality" (2:142), Nicholas I and Pushkin are treated here with equivalent respect. Each was eager to impress the other, each needed the other, and each had to struggle to approach the other with an open mind (1:143). Tyrkova's willingness to see matters also from the tsar's point of view - to defend his imperial sense of honor as well as the poet's - is unusual for Pushkin biographies. The sympathy begins with her account of the Decembrist debacle (Chapter 7, "Rokovoi den'” [2:107-19]). It ends 300 pages later, with her impassioned defense of Nicholas I against the slanderous "legend" of his seduction and conquest of Natalia Nikolaevna, 
an insinuation leveled by P. E. Shchegolev in 1911 and reprinted in Bolshevik Russia in 1928 (2:462-67). ${ }^{7}$ Such open-minded sobriety complements Tyrkova's humanistic liberalism in other areas, imparting to her biography an intonation neither native nor émigré.

Tyrkova devotes some time to the Decembrist Uprising, explicitly basing her account on a memoir that Tsar Nicholas I wrote for his children in 1835. The misunderstandings and anguish of that day are given largely in his royal zone. We learn of his rigid upbringing, his ignorance of his brother Konstantin's renunciation of the throne, his utter unpreparedness to rule, his desire to do his duty while not knowing in what it consisted, his awareness of his own unpopularity among the soldiers, officers, and at court (and thus his reliance on his loyal friend Benckendorf during those awful hours of the interregnum). Finally she considers Nicholas's valiant but vain efforts to prevent bloodshed. The tsar-elect had lists of suspects and could have moved with preemptive arrests. Why did he not do so? Harsher measures undertaken sooner would have averted the catastrophe, Tyrkova insists, especially since the conspirators themselves had lost hope in the success of their enterprise by the night before (she considers Prince Trubetskoi's failure to turn up on the Square an act of great courage [2:111]). Nicholas hesitated, she argues, because he admired these men, acknowledged their sense of honor [chestnost'], and was horrified at their fantastically unreal plan. She notes that after the disaster of the Crimean War had exposed the corruption and incompetence of the Russian army, Nicholas, by then close to death, said bitterly: "My friends the Decembrists would never have done this" (2:118).

All in all, Tyrkova rather takes Tsar Nicholas's side — and invisibly allies Pushkin with it. The "soft-hearted dreamer" Ryleyev (who was present on the Square, and executed) and the sober, commonsensical Pushkin (who was absent, and spared) are grouped together. "Had they managed before the uprising to share their mental experience, perhaps they could have restrained the conspirators from an armed demonstration" (2:102). This reading of events is certainly not the conventional "Poet versus Tsar." It cannot surprise us, however, coming from an exiled Constitutional Democrat turned Pushkin

7 Together with the shut / tut controversy in Mikhailovskoe Notebook \#2368, this flare-up of anger at unjustified slander of the Romanov dynasty constitutes Tyrkova's major corrective incursion into 20th-century academic Pushkin scholarship. Shchegolev's "Duel and Death of Pushkin" is a well-documented study, she notes, except for this one sensationalist rumor - present in innuendo, dependent upon unreliable French sources, and designed to portray the Russian tsar as some "Asiatic monster" (2:463, author's note). 
biographer, disillusioned with the Decembrist Myth that had polarized one hundred years of subsequent Russian politics.

Ten more years of wary relations between Russia's premier soldier and her premier civilian poet is half of the story left to tell in Volume 2. Tyrkova interweaves three factors, each with an anti-Bolshevik, anti-bureaucratic edge. First comes Pushkin's post-Decembrist loyalty to the imperial principle and the monarchical system, blunted (both then and now) because his friends insisted on seeing in him the pre-exile firebrand. That reality, she insists, was no more. Then there is the poet's idealization of Nicholas I, not wholly without cause. After September 1826, Pushkin enjoyed no more audiences with the tsar until the time of his marriage, when the two men began to meet very cordially in Tsarskoe Selo; "[d]uring those five years, Pushkin's feelings toward the tsar had not changed, and if anything had strengthened" (2:318). Finally, there is the irritant of mindless censorship, and Pushkin's ignorance (willful or naive) regarding the constant surveillance to which he was subjected by Benckendorf's network of spies. Tyrkova makes much of the fact - an accident of those terrible days of the 1825 interregnum - that this Chief of Gendarmes, a "limited and desiccated careerist," ignorant and suspicious of all enlightenment, was one of the few men whom Nicholas trusted (2:215-16). Pushkin was so good-natured, so patient and selfrespecting that he never suspected the extent of the constraints under which he labored. Each time some random caprice came to light (an intercepted letter, a slanderous accusation), he was startled and enraged anew. By the time he bolted for Arzrum, he probably suspected the truth.

As a weaver of contexts and circumstance, Tyrkova-Williams shows us Pushkin striving to realize his fate in the proper way. But others have their fates too - and the role of chance events in these multiple unfoldings is left open. Driving with his second, Danzas, to the site of the duel, relaxed, in good humor, at last on his way to defend his honor with a weapon in his hand, Pushkin jokingly noted that they were taking a roundabout path. "Danzas had deliberately chosen a well-peopled route, hoping that someone would notice them and stop them," Tyrkova writes (2:485). "Benckendorf could not have been unaware of the duel underway. The entire city was talking about it, including the tsar. How many times the gendarmes had prevented duels. This time they did nothing." The final act of this drama between poetry and bureaucracy was fought not over Pushkin's body but over his unpublished papers, which Benckendorf wished to seal up but which Zhukovsky insisted be inventoried under his supervision (2:502-3). The tsar's benign consent is part of that posthumous struggle as well. Only 
at the very end, as the dead genius is being slipped into his grave attended more by gendarmes than by family or friends, does Tyrkova allow Nicholas I, from whom the poet had expected so much, to reveal his hand. "The tsar had no authentic respect or friendly feeling for the slain man," she concludes (2:499). When Prince Paskevich-Erivansky remarked that he regretted the loss of the writer Pushkin at a time when his talent had just matured "but as a man he was no good [durnoi]," the Emperor answered: "Your opinion about Pushkin I share absolutely." For all its delicate balancing, then, the theme of "Poet and Tsar" ends as in Tsvetaeva's 1931 poem of the same name: in the "otherworldly hall of the tsars," the marble statue of Nicholas I is nothing more than a "pitiable gendarme of Pushkin fame."

The other half of the story that Tyrkova tells in Volume 2 is Pushkin's quest for the right woman. The transitory muse gradually gives way to the gentle ideal of Tatiana and then to the necessary wife. Women writers who love Pushkin and take up the task of recreating the poet's life are a fraught category, not free of a certain possessiveness, in part because of the magisterial twentieth-century accomplishments of Tsvetaeva and Akhmatova in this realm. As a biographer, Tyrkova-Williams is a product of the nineteenth century, and she enjoys certain benefits by being no poet herself. Chernyshevskian traces of an intelligentka's view of women's rights and appetites - where women too are agents, able to calculate their own best interests - suffuse her image of Pushkin in his successive roles of Don Juan, bridegroom, and husband. Two points are made repeatedly. First, that physically Pushkin was extremely undistinguished: short, fat-lipped, kinkyhaired, "just like a monkey" (the candid opinion of the gypsy singer Tania, 2:159-60). And second, that women found Pushkin irresistibly attractive, from his adolescent years to the day of his death, and responded rapturously to his overtures. Women were the hungry ones. Pushkin was fussy, even though he always had more than enough.

Tyrkova opens Chapter 11, "Baryshni" [Young Ladies] with the remark that "many people who are highly susceptible to falling in love require a single great feeling. Pushkin was one" (2:168). Unlike Binyon, who presents Pushkin's libido as goatishly indiscriminate, and unlike Surat/ Bocharov, who present it largely as a prompt for magnificent love lyrics, Tyrkova offers us a disciplined, fully rational quest on the poet's part to lose control and be bound to a fated love. Sophie Pushkina, Ekaterina Ushakova, Annette Olenina, all these trial runs were quickly forgotten and caused the poet little grief. Part Three of Volume 2, titled "In Pursuit of Happiness (1829-1833)," begins with the long-awaited moment when Pushkin, now 
smitten by Tasha Goncharova, realized, with relief and dread, that he was no longer free. His behavior as a bridegroom was bizarre. And "there was something strange, wrong, non-Pushkinian about this marriage, in this striving to attain the hand of a girl who had done nothing to indicate that she loved him, or that she found him attractive" (2: 264). Once the step was taken, however, and Pushkin had adjusted his muscular organism to the pressures of the new regime, he was ecstatic. Tyrkova notes that Tasha Goncharova became Pushkin's wife to the buzz of much skeptical gossip. She was sloppy, disorderly, tasteless in her attire; "Moskovshchina was reflected in her rather noticeably" (2:305). How could this untutored girl become the consort of a great poet? But "Natalia Nikolaevna had good reserves of inborn female intuition" (307); she knew how to adjust. In fact she learned household management rather well. The couple became known as superb, if extravagant, hosts. It was this pliability, combined with the indispensable absolute beauty, that made her precisely the sort of woman to whom Pushkin desired to lose his freedom.

Chapter 20, "Zhenatyi Pushkin," goes further than the other biographies in defending the integrity of the wife. If Binyon tends toward the sentimental, positing a powerful but involuntary change in the poet after he experienced marriage and especially fatherhood, Tyrkova insists that Pushkin consciously constructed the gilded cage of his home life. Friends were astonished at his happiness. Natalia Nikolaevna had always been indifferent to the poetry, but "it is possible that Pushkin, especially at the beginning, found a reassuring charm in the fact that for Nathalie he was simply a husband and not a famous poet" (2:308). Nathalie was a skilled embroiderer - it was her one "domestic skill" - but "she soon gave it up, in order to devote herself fully to that which her husband considered her true calling: the entertainments of high society" (2:331). Her jealousy too "delighted him and consoled his male vanity" (316). Of the couple's four children Tyrkova speaks little; their names and birth dates are provided in one brief paragraph (2:342). Her focus is everywhere on the passionate bond between husband and wife, presented as deeply satisfying both physically and spiritually. If there is foolishness on one side and Pygmalion on the other, Tyrkova does not speculate about it.

By 1834 these two themes, the tsar's court and the necessary wife, were dangerously interwoven. Several events are highlighted as fatal: the insult of kammerjunker rank, the insult of the intercepted letter, the strain of settling the two older Goncharov sisters in the Pushkin household (a move the poet tried to prevent). Having molded his wife into the perfect temptation, he now had to shoulder the risk and the cost. But the cage was too transparent 
and the strands tying him to power too compromised. Tyrkova (like Binyon) considers the attempt of a beleaguered Pushkin to resign from service in 1834 a "reasonable request." But she also understands the tsar's fury ["Tsar' razgnevalsia"], quoting his regal word that archival access was granted only "to people enjoying the special trust of the authorities" (2:379). Pushkin's desire to withdraw from the world - from that world - for the sake of his work, family and sanity was not only a suspension of service; it was a betrayal of trust.

These two massive vulnerabilities of Pushkin, his wife and his Emperor, receive a parallel reassessment in Tyrkova's final chapters. In 1825-26, the new tsar was treated sympathetically, as the carrier of a valid point of view on Russian society and personal honor that Pushkin largely shared. Pushkin nurtured this ideal throughout the 1820s, fretting at bureaucratic caprice and stupidity but careful to separate this unpleasantness from the Sovereign's name. But as the end nears, and even more so after the end, Tsar Nicholas emerges in his true colors: an unworthy object of hope. Likewise, Pushkin's passionate devotion to his wife (and to his self-fashioned ideal of a wife) is supported by Tyrkova enthusiastically as long as the poet himself considers it a challenge and is able to cope. But by Part Five of Volume 2, titled "The Predictions Come True (1836-1837)," Pushkin can no longer cope. Accordingly, Tyrkova's tone toward Natalia Nikolaevna changes abruptly. She ceases to consider whether this wife was what the poet wanted her to be, and the narrative takes on the carping "mean-to-Nathalie" tone that is routine in accounts of Pushkin's life.

To sample but a single page (2:446). "She was drunk on her own beauty, it turned her empty little head," Tyrkova writes; poetry readings in her presence never bothered her because, as she was proud to announce, "All the same I don't listen." She continued to call Pushkin and his friends by the condescending term sochinitel' [something like "hack writer"] rather than writers or poets; and "no one has preserved for posterity a single one of her witticisms, not a single apt remark" (2:446). D'Anthes was not her only suitor, and toward all of them she acted the same: laughing, posing, wounding her husband. "This frivolous, empty woman filled her life not with love, but with a play with others' feelings." At this point it crosses the reader's mind that Tyrkova is reacting to Pushkin's wife as would a radical intelligentka of Chernyshevsky's generation, for whom seriousness of purpose and the ability to carry through on a feeling were virtues more to be prized than spousal fidelity. Natalia Nikolaevna, it now seems, was too trivial and dishonest even to consummate her own flirtations. At home she 
still graced the hearth, laying her lily-like head on her husband's knee, but "it was enough for her to don a ball gown and she was transformed from an affectionate wife into a frivolous coquette" (2:473). Thus does the wife emerge in her true colors: an object unworthy of love. Hope, trust, love: of all this the poet was stealthily deprived. Only honor remained wholly under his own control, and the duel was its instrument.

What might we learn from these three different Lives of the Poet? Binyon's biography was a major breakthrough: the most ambitious, thorough, irreverent and best written page-turner on Pushkin's life that we are likely to have in English for some time. Surat/Bocharov was less a pioneering effort than a culmination: an immensely stretched-out elegy in prose, composed in the reverent, abstract and uncritical spirit of Russian tributes to their great poets. The two volumes of Tyrkova-Williams, appropriately for an expatriate Russian writing in London, fit in between these two extremes, longer than the former but as compassionate as the latter, beholden to no special pieties but the one that also held Nabokov fast: an émigré's love for an unrecuperable past. We are left with several interesting questions. Which is the more reasonable portrait to attempt: the outer or the inner man? Must the history of a private life, in order to qualify as demythologized and "real," be reduced by the biographer to byt - that is, to a record of everyday observable habits and pleasurable or stressful routines? Grigory Vinokur discussed these issues in his 1927 study "Biography and Culture," drawing heavily on Pushkin's life. ${ }^{8}$ The terms "inner" and "outer" are of course hopeless when each is taken alone, he writes (34); biography, as "the history of a private life," must assume that one is conditioned by the other. Pushkinists of the "Did Pushkin smoke?" persuasion, who limit themselves to "counting the number of bottles drunk up or the property gambled away," have only themselves to blame when "their Pushkin comes out not Pushkin, but Nozdryov" (22). At the other pole, biographers of the "spiritual life" err in their willful self-serving application of psychology, which (Vinokur cautions) "apparently enjoys unlimited and absolute rights in this region,

8 G. O. Vinokur, "Biografiia i kul'tura" [1926, published 1927], in Biografiia i kul'tura / Russkoe stsenicheskoe proiznoshenie (Moscow: Russkie slovari, 1997), 17-88. Page numbers in the text. 
where we make bold to enter with our own goals" (23). Most desirable is a synthesis of the two, which Vinokur would seek in "concrete psychology." In such a method, "biography is not so much a problem as a source" (26). To re-create a personality [lichnost'] in its own time, the most difficult task facing the biographer is to define the filter, that is, the optimal procedures for the selection of material.

Over the subsequent two decades, Vinokur, one of the great Soviet-era Pushkin scholars, had ample opportunity to experience within the Stalinist literary establishment the anxiety that can attend a correct selection of material. In 1927, the political imperative was not yet decisive. On the far side of Communism, however, the politically conditioned aspects of canonized biography have once again become a point of contention. Here Feliks Raskolnikov's work on Pushkin can serve as instructive closure.

\section{Post-communist sobriety (a coda on Feliks Raskolnikov)}

Part One of Stat'i o russkoi literature (2002), titled "Pushkin," contains seven essays written between 1987 and 2002. The topics range from close readings ("Arion," Boris Godunov, Pir vo vremia chumy, "Pikovaya dama," and Skazka o zolotom petushke) to topics of more thematic sweep ("The criminal in Pushkin as a tragic figure"). These discussions contain bold, at times eccentric, almost always provocative interpretations of individual works. But as a coda to this review of Pushkin biographies, it is Raskolnikov's threepage "Introduction" justifying his volume (9-11) that is most immediately relevant. In it he suggests that a critic's "selection of material" is not innocent in either direction: the works are always stitched into the life, and life-values are inevitably extracted from the works.

The time of his book's writing coincides with a historical arc stretching from perestroika to the present day. During that period the Communist system of controls weakened, collapsed, was overwhelmed by a chaotic multiplicity of alien or previously suppressed methodologies, and then literary study attempted to cleanse itself. Raskolnikov, in emigration since 1979 and for many years a professor at Michigan State University, has been chronicling this process from a distance for two decades. All the essays collected in his book (which discuss, in addition to Pushkin, texts by Lermontov, Gogol, Chekhov, Esenin, Pilnyak, Gorky, and Sholokhov) are unified by one task: to counter the hasty and overwrought post-Soviet correctives to Communist clichés with further correctives from a more 
dispassionate Western-outsiderly perspective. Himself a methodological conservative, Raskolnikov is concerned to stabilize Pushkin's life and snatch it back from the backlash.

His argument is straightforward. Pushkin's mature period (1830-36) is the phase of the poet's life least honestly analyzed by Soviet scholars. Obliged to exaggerate his "revolutionary" support of the Decembrists, to muffle his move toward enlightened conservatism, and to ignore his spiritual evolution, these researchers piled up authoritative but isolated lifefacts and literary facts that did not illuminate one another. Taboo themes were left to Western Pushkinists or Russian religious scholars writing in the diaspora - and for the most part were treated subjectively, at times impressionistically. After 1991, this mandate for an atheistic, politically radical Pushkin dissolved and the opposite extreme was indulged. Veteran Pushkinists such as Georgy Lesskis and Valentin Nepomniashchy began to argue that Russian Orthodox Christianity and the messianic, ascetic ideal (with its resistance to rationalism, hedonism, commercialism, and Western-style individualism) lay at the core of all Pushkin's creativity. This corrective was valuable, Raskolnikov affirms. But a profligate Christianization of all the texts was clearly also unbalanced. The erotic, lifeaffirming Pushkin as closet ascetic has as much basis in fact as the Partyapproved image of Pushkin, proto-Bolshevik. "Having focused their attentions exclusively on religious motifs in the works of Pushkin, they now 'ideologized' and simplified him, although differently than the Soviet literary scholars had done" (11). And so Feliks Raskolnikov moves steadily through the corpus, seeking an objective (ideally a golden) mean between the theses of Communist-era unfreedom and post-Communist reflexes against that unfreedom.

Comparativist biographical and literary scholarship received powerful impetus from the Pushkin Bicentennial. We can expect successive waves of such counter-correctives in future years. Inevitably, as Pushkin's receding world becomes ever more illegible, as the Russian tradition of scrutinizing its literature for clues to "what it means to be Russian" gives way to more global pursuits, and as poets cease to be front-line martyrs for the political folly of the day, we will look back on the Pushkin Myth that flourished for two centuries as a primary literary fact. Whether exposé, reverent tribute, or thick description will best serve to keep the poet alive in his native medium is a question for later generations and ever-wider readerships. 